\title{
History of Mathematics in the Netherlands: Where to find it
}

\author{
Danny Beckers (Vrije Universiteit, Amsterdam, The Netherlands)
}

It is only somewhat exaggerated to state that the history of Dutch mathematics can be learned through the history of the Royal Dutch Mathematical Society. The society is, at least, a good place to start if you want to find out more about the history of Dutch mathematics. The Amsterdam University Library, Department of Special Collections (http://bijzonderecollecties.uva.nl/en), together with the Holland State Archive (http://noord-hollandsarchief.nl/ bronnen/archieven) in Haarlem, keep most of the collection of the society. The first collection, in the centre of Amsterdam, holds the library of the society. The second holds the archive of the society, which has been kept rather meticulously up to date by the librarians of the society.

Before going into detail about what you may or may not find in these two locations about the history of Dutch mathematics, first we will cover some details about the history of this peculiar society. It was founded in 1778 and it is from those days that it inherits its motto "untiring labour overcomes all". Both the society and some of its active members have helped to commemorate and keep alive the history of Dutch mathematics. The society started as a small, local initiative by some well-to-do Amsterdam citizens, who were concerned about the economic state of their country. They made a living in mathematics, that is, they earned money thanks to the results of calculations, measurements and their knowledge of maths, in the capacities of surveyor, accountant, engineer and teacher. They thought that the Dutch Golden Age (the years of economic growth and colonial expansion following the successful revolt against the Spanish king) had resulted from superior mathematical knowledge the state of which they found lacking in their days. Convinced of the value of maths for their respective professions and even more for the wellbeing of their country, they wanted to spread knowledge of the subject to as many people as possible. In fact, this small Amsterdambased society was one of many societies at the time that were founded by like-minded people in various places [Beckers 1999].

This small-scale Amsterdam Society gradually changed its character. In Europe, these societies were quite common. Most of them disappeared during the 19th century when mathematics as a formal academic discipline arose and the idea of pure mathematics became the epitome of maths. This particular Amsterdam society was different because it sought the cooperation of academics to strive for solid standards in maths education. Thus, when these academics in the late 19th century strove for a professional organisation of their own, the society was the obvious place to start. Contrasting with other Euro- pean countries, where national societies were founded in the second half of the 19th century, the Dutch, with a very small academic base, already had their organisational structure firmly established: by 1875 , it was mostly the academic mathematicians who could and would spare the time to actually keep the society alive [Beckers 2001].

The concerns of the society are beautifully reflected in its publication policy [Alberts and Beckers 2010]: around 1800 publications, consisting mostly of textbooks and a somewhat megalomaniac project of translating Montucla's Histoire des Mathématiques in four volumes [Montucla 1784-1804]. At irregular intervals, journal quires were distributed, mostly containing exercises and solutions and sometimes a paper on a mathematical subject. From 1875 onwards, there was a steady flow in the society's journal, from then on called the Nieuw Archief voor Wiskunde. Exercises were still published but the journal started publishing short mathematical research papers. It became increasingly difficult to keep teachers involved. By 1900, the society published the Nieuw Archief, an international review journal, the Revue Sémestrielle, and a journal containing series of exercises and solutions. By that time, accountants had already left the society, insurance calculators were organising themselves within a separate society with their own journal and maths teachers wanted their own journal. At the time, the board of the society, anxious that the teachers might also leave the society, decided to fund the teachers' initiative. From this, and other teacher journals, in the 1920s emerged the Dutch Maths Teachers Association [Blom 1998]. Until the 1920s, the society managed to keep its international position by balancing the needs of the teachers and academics nationally whilst, at an international level, using the advantage of being a small country that no one feared and actively reconciling and looking after everyone's interests. This worked until the great depression. From then onwards, the society had to discontinue many of its efforts. Only the Nieuw Archief was continually published.

After the Second World War, the society briefly sparkled again, for example organising the International Mathematical Conference in Amsterdam in 1954. But in the new structures the society and its members helped build, it soon became just one of the national players. The Mathematisch Centrum (Mathematical Centre), founded in Amsterdam in 1946, for example, would be leading the way in how mathematical research was going to be organised and funded in the Netherlands [Alberts 1998]. This centre would launch the Netherlands into the computer age, bluffing their way in by presenting a computer that only worked once [Alberts and Van Vlijmen 2017]. 
It built quite a name for itself in computer science, harbouring famous people such as Adriaan van Wijngaarden (1916-1987) and Edsger Dijkstra (1930-2002). For that reason, it changed its name in 1983, and nowadays the Mathematisch Centrum is known as the Centrum voor Wiskunde en Informatica (CWI, Centre for Maths and Computer Science).

Meanwhile, the Dutch Mathematical Society dwindled. Teachers had virtually left it and the Dutch research community (who wanted to know who was getting appointed or retired and where) were better off with the Dutch Teachers Association, which at least published many of the public lectures in its journal. In contrast, the Nieuw Archief voor Wiskunde tried to keep up its prewar appearance of an international research journal. At the end of the 20th century, the society re-invented itself. From 2000 onwards, its journal was restyled and, since then, has functioned as a journal informing all Dutch speaking mathematicians - in the broad sense of the word (http://www.nieuwarchief.nl/serie5/index.php). It received royal status in 2003.

Let's return to the two places mentioned at the beginning where you can find the collection of the society. Special collections in Amsterdam, apart from the book collection, contain absolutely stunning 17 th and 18 th century manuscripts on navigation, recreational mathematics and accounting. They were collected by the 18th and 19 th century members of the society and were intended to illustrate the glory of the Dutch Golden Age of mathematical knowledge. It also contains the manuscripts of these early members, which are just as interesting. For example, among the manuscripts that one of the early members of the society donated is an absurd recreational mathematics exercise from a book by Heinrich Meissner.
It resulted in a polynomial of degree 28 with huge coefficients. To avoid mistakes, two of the early members of the society calculated and recalculated all the steps in the process and checked the results against each other before actually writing their result on a 2.5 metre long leaf of paper. The 1907 version of the catalogue of the society's library, also containing the list of manuscripts, is available online via the library catalogue (or at https:// www.wiskgenoot.nl/sites/default/files/afbeeldingen/watbiedt/Publicaties/SysCatBoekerijWG1907.pdf).

The Archive in Haarlem contains, among other things, the minutes of the board. The very first book of minutes has, in a rather embarrassing way, been destroyed in an argument among the early board members [Engelsman 1978] but all the others have been preserved. Many other things one might expect to find in a society's archive are also there: correspondence and reports from its various committees and information about its finances and the library.

What would you miss if you restricted yourself to the society? Well, quite a lot, really. But it is easy to use this story about the society as a way to fill in the gaps and, in many cases, you may already find yourself in the right place - or just around the corner. From the history of the society, you can work out what is missing: academic mathematics before the society became of national importance; all mathematics predating the founding of the Dutch Republic; all history of mathematics education from the 1920s onwards; and, last but not least, the history of the new institutions arising after World War II.

We start with the easiest one. Of the new institutions arising after World War II, the archives of both ZWO (the funding agency that was started after the war to regulate the financing of pure scientific research) and the

The Library of the Royal Dutch Mathematical Society is held by the Special Collections Department of Amsterdam University. It contains many publications by the members of the society but it also has a huge collection on Dutch Golden Age maths books, such as the Wisconstighe Gedachtenissen (1604-1608) by Simon Stevin and publications by Frans van Schooten, Jr., and Christiaan Huygens. During the 19th century, the society systematically started collecting all important mathematical publications, so one can find everything by Gauss and others. The collection was freely accessible to members until the early 20th century and since then it is accessible to everybody. Since 1894, it has steadily been growing, since the society was supporting the publication of the review journal, which made its library the accumulation point for all math publications in the world. Moreover, the library contains many manuscripts, among them several 17 th and 18th century manuscript versions of important textbooks on navigation by Klaas de Vries and Hendrik Gietermaker but also a stunning 15 th century manuscript on root extraction, a beautiful 18th century manuscript on the construction of sundials and many 19th century manuscripts by society members, including lecture notes and other scribbles. Some, like the one in the picture, are simply solutions to textbook exercises but contain beautifully coloured drawings. The picture beautifully reflects the interests of the society members around 1800 .
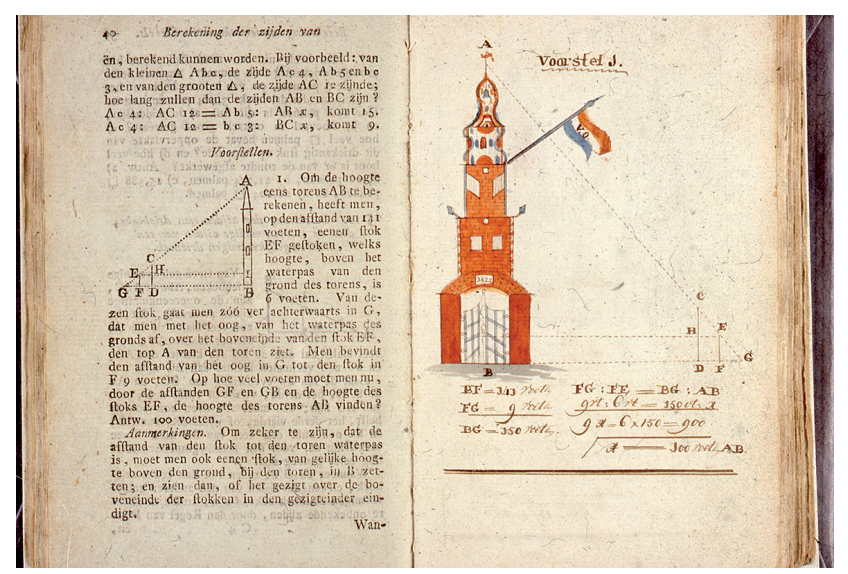

Manuscript with colored drawings. Excercises and solutions in a textbook from the library of the society. Bijzondere Collecties Universiteitsbibliotheek UvA Amsterdam. 
Mathematical Centre (the present-day CWI) are also in Haarlem. So you may find yourself in the right spot. The personal union that existed in the early years between the society and the new institutions made them preserve their archives in the very same spot.

Slightly more difficult is mathematics predating the founding of the Dutch Republic (1581). The material consists mostly of textbooks and learning texts on commercial and ordinary arithmetic and some elementary geometry. It is scattered around the globe in various libraries and (private) collections but has been made accessible by Kool [Kool 1999].

Regarding the history of mathematics education, the most important archives happen to be in Haarlem too. There, the archive of the Dutch Maths Teachers Association is kept. Archives of several important people in Dutch maths education are there as well. A valuable source for information is the journal of the Dutch Society for Mathematics Teachers, which has recently been digitised and made available online by the society (https://archief.vakbladeuclides.nl/). You can access it from Haarlem but also from anywhere in the world. The journal has existed since 1924 and is a great source because many Dutch mathematicians kept in touch with maths teachers through this journal.

Last but not least, a difficult point is finding archives of Dutch mathematicians. Let's start with the good news: for some of these archives, Haarlem is the place. The personal collections of famous mathematicians such as Hans Freudenthal (1905-1990) [La Bastide 2006], David van Dantzig (1894-1959) [Alberts 2000], N.G. De Bruijn (1918-2012) and several others are preserved there. But additional material and archives not deposited in Haarlem are more difficult to trace. After 1850, if archives were preserved, the mathematical society will at least have made an effort to keep them safe for future generations. You will, at least, find the name of your subject in the archive or the library of the society, which might provide a hint as to where to look for more information. In general, there are two places to look for archive material: either in the archive of the university where the individual was appointed or in the archive of the organisation that appointed them. As an example of the latter, between 1815 and 1968, some of the universities were state funded so appointments and sometimes more archive material can be found in the Archive of the Home Department (since 1918, the Ministry of Education) in The Hague. Other universities were privately funded or paid by the municipality so one can find more material in the archive of the funding organisation - usually kept in a municipal archive. Furthermore, to keep things interesting, after 1850, there were chairs (also at the state universities) that were funded by private organisations. Moreover, before 1850, there were quite a number of people outside academic circles who contributed enormously to Dutch mathematics.

Here are a few examples. Leyden University was founded in 1575 . Soon after, a curriculum for mathematics in the vernacular was laid down. It was intended for the training of engineers that could help in the war, in fortress building and water works [Krüger 2014]. Other universities, with mathematicians teaching there, were founded in the late 16th and early 17th centuries; both Latin and vernacular curricula were taught. Some of the surviving lesson plans and syllabi are in the possession of university libraries and these have been partly digitised. Most university libraries have made policies (although most of these have been discontinued due to budget cuts) to collect papers of other important scientists as well. For example, the scientific notes by Christiaan Huygens can be found at Leyden University. Another early 19th century example is the Utenhove Collection of the Utrecht University Library. This mathematically interested (and well versed!) baron donated his entire library to the University of Utrecht and it has been kept there ever since.

If a mathematician worked at a particular university, you are likely to find their papers at that very place. Not all of these notes are in the libraries where you might expect them, though. For example, part of the lecture notes and papers from the Leyden mathematician Frans van Schooten, Jr., (1615-1660; editor of the Latin translation of Descartes' Géométrie, published 1649) can be found at the Groningen University Library [Dopper 2014]. The papers of the Frisian Academy at Franeker, which no longer exists, are scattered across the globe [Dijkstra 2012]. Many of these particular papers have meanwhile been digitised (see http://facsimile.ub.rug.nl/ cdm) but since this is, in general, not (yet) the case, it is necessary to visit the individual library catalogues to see what the various institutes hold. More recently, the lecture notes of Eindhoven Technical University Library have been made available online (https://www.win.tue. nl/doc/AntiekeWiskundeDictaten/). Among these, for example, are the handwritten, photocopied lecture notes of Edsger Dijkstra on formal programming that were used there until 1990.

Most universities will, moreover, hold archive material on their former employees. Sometimes these will only consist of a track record but a few letters or a description of their library are often present. Sometimes entire libraries, including manuscripts, are kept by university libraries. Special collections at the Amsterdam University Library have already been mentioned but there are several of these kinds of collection that might be of interest. The Bierens de Haan Collection of Leyden University Library is another example, in this case collected by one of the former professors of mathematics at the university.

University libraries in the Netherlands are all committed to having their collections searchable on the web. Most of the material, although not always manuscript collections (entirely), is thereby accessible through Worldcat. That doesn't necessarily imply that they also make their collections available online. The Dutch Royal Library in The Hague hosts, with the cooperation of many university libraries and other institutions, a digital library Delpher (http://www.delpher.nl), focused on books, journals and newspapers. Among those, many things of interest to the historian of maths are to be found (the journal Nieuw Archief voor Wiskunde of the Dutch Mathemati- 
cal Society is due to appear there completely in 2018) but, as an archive source, the transcription of radio bulletins broadcast between 1937 and 1984 is most noteworthy. Unfortunately, the search options are only available in Dutch. Another online initiative is by the Dutch Royal Academy of Sciences. The website of its history institute supports several digitising initiatives, covering many books and manuscripts of Dutch mathematicians (https://www.huygens.knaw.nl/resources/?lang=en).

If all the above doesn't help, one has to start digging in municipal archives. Even if you have found a lot about a mathematician, it might be a good idea to check out such a place. Although some of the smaller municipalities in the Netherlands are closing their archives, many of them still support their own archive service. If they have discontinued their archive then the papers are stored in one of the archives still active in the region. If you are lucky, the municipality where you want to be has registered its archives with the central website for archive searches (www.archieven.nl/en). Many have but unfortunately not all of them. The Haarlem collections may be found through this service. Municipal archives will usually contain archive material on people or organisations of particular interest to the municipality, including local (mathematical) societies and clubs that were founded during the late 18th and early 19 th centuries. So, the Leiden Municipal Archive preserves what is left of the Leyden Mathematical Society Mathesis Scientiarum Genitrix (1785). The Groningen Municipal Archive preserves the archive of Minerva, a technical school that held local mathematics contests during the early 19th century. Mathematicians naturally participated in these kinds of activities, just as they may have served on the boards of local organisations whose archives are kept in these places.

Finally, it is worth mentioning the collections of a few museums. The history of science museum Boerhaave in Leyden not only has a great collection of mathematical instruments, including Napier rods, measuring instruments and a rather intriguing object from the early history of the Dutch Mathematical Society [Engelsman 2004], but it also holds an archive with a number of letters and personal objects from noteworthy mathematicians, such as W. Kapteyn (1849-1927). It also includes letters from internationally renowned figures like Albert Einstein and Paul Ehrenfest.

The Amsterdam Scheepvaart Museum holds a beautiful collection of nautical instruments - including interactive working explanations - besides a room filled with maps. At the school museum in Dordrecht, you will find all kind of educational objects, as well as a huge collection of textbooks. Mathematical puzzles and games can be found in Teylers' Museum at Haarlem.

Since the late 1990s, a special committee assigned by the Royal Dutch Mathematical Society has taken up the task of systematically collecting and preserving the archives of distinguished mathematicians. This Commissie Persoonlijke Archieven Wiskundigen (CPAW; Personal Archives of Mathematicians Committee), a permanent commission of the Dutch Mathematical
Society, helps to preserve archive material, both actively and passively. It convenes once or twice each year and its members actively approach retired mathematicians of renown to ask them to consider donating their archives. The active collaboration of the committee with the archive at Haarlem has secured the storage of the archives of several scholars of renown [Alberts, Koetsier and Bolten 2003]. Some of the archives are kept in storage in Amsterdam at the CWI. There is a list available at https://www.wiskgenoot.nl/persoonlijke-archieven-vanwiskundigen. Although it does take time and money to make these archives accessible and, indeed, some of the archives are not yet open to the public, inquiries about particular archives can always be made through the committee.

Archives at the committee's disposal are usually ordered by the former owner, the advantage being that relatively many archives then end up in the hands of the committee. The obvious disadvantage is that the archives clearly only consist of what the owner wants to be remembered for. Being a historian, one should always be aware that archives never speak for themselves and even obvious facts should be checked against other data, if possible, or should be completed with other findings. The ordering of the Freudenthal Archive is a beautiful case in point. The archive was clearly a way for the former owner to emphasise his lifelong interest in mathematics education and it clouds the fact that he was much more occupied with mathematics until the late 1960s. Every letter and snippet about the Dutch Committee for Modernising Maths Education is there, suggesting that Freudenthal was actively involved from the beginning. One needs to visit the Dutch State Archives in The Hague, where the minutes of this committee are kept, to find out that he never attended a meeting and only started actively contributing in 1967 [Beckers 2016].

You may have noticed that archive material concerning the history of mathematics in the Netherlands is scattered across the country in a variety of institutions. So, despite (or as a result of) having read the above, if you don't agree with the idea that the questions of your par-

Maquette by one of the early members of the Dutch mathematical society. See [Engelsman 2004]. Collection Museum Boerhaave, Leyden, inv.nr V10256.

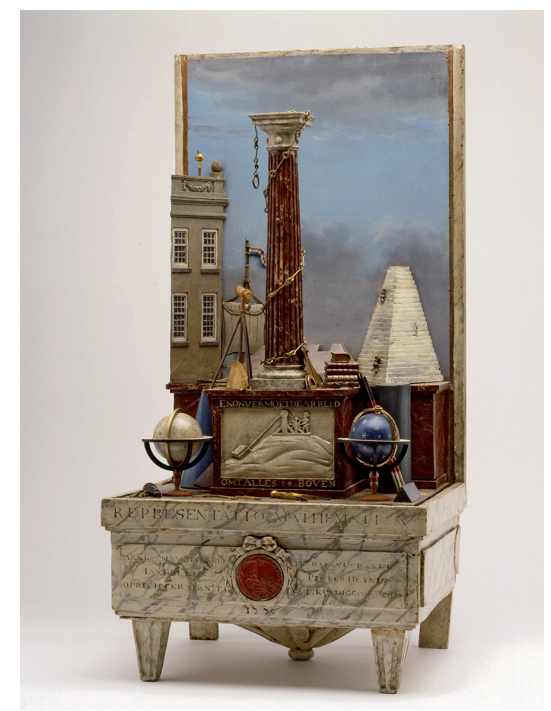


ticular interest are best approached through the collections of the Royal Dutch Mathematical Society or the collections that have been assembled with the help of one of the society's committees, you will certainly have to agree that it does bring quite some advantages in travelling arrangements to start from there!

\section{References}

A website with an introduction, bibliographical overview and various sources is maintained by Prof. Dr. Jan Hogendijk, University of Utrecht, http://www.jphogendijk.nl/.

Alberts 1998: Gerard Alberts, Jaren van berekening. Toepassingsgerichte initiatieven in de Nederlandse wiskundebeoefening 1945-1960, Amsterdam: AUP (1998).

Alberts 2000: Gerard Alberts, Twee geesten van de wiskunde. Biografie van David van Dantzig, Amsterdam: CWI (2000).

Alberts, Koetsier and Bolten 2003: Gerard Alberts, Teun Koetsier en Godelieve Bolten, Snippers met formules. Archieven van wiskundigen, in: Nieuw Archief voor Wiskunde (V) 4 (2003), 46-50.

Alberts and Beckers 2010: Gerard Alberts en Danny Beckers, Wiskunstige Verlustiging. De tijdschriften die het genootschap wel en niet uitgaf, 1770-2000, in: Nieuw Archief voor Wiskunde (V) 11 (2010), 20-26.

Alberts and Van Vlijmen 2017: Gerard Alberts en Bas van Vlijmen, Computerpioniers. Het begin van het computertijdperk in Nederland, Amsterdam: AUP (2017).

La Bastide 2006: Sacha la Bastide - van Gemert, "Elke positieve actie begint met critiek". Hans Freudenthal en de didactiek van de wiskunde, Hilversum: Verloren (2006).

Beckers 1999: Danny Beckers, "Mathematics our Goal!” Dutch mathematical societies around 1800, in: Nieuw Archief voor Wiskunde (IV) 17 (1999), 465-474.

Beckers 2001: Danny Beckers, "Untiring labor overcomes all!" The Dutch Mathematical Society in comparison to its various counterparts in Europe, in: Historia Mathematica 28 (2001), 31-47.
Beckers 2016: Danny Beckers, Wiskundige voor een betere wereld. Hans Freudenthal (1905-1990), in: Vittorio Bussato, Mineke van Essen en Willem Koops (red.), Zeven Grondleggers van de Onderwijskunde, Amsterdam: Bert Bakker (2016), 113-158.

Blom 1998: Klaske Blom, Van de akten van bekwaamheid, Utrecht (1998), http://www.jphogendijk.nl/projects/ActenvanBekwaamheid.pdf.

Dijkstra 2012: Arjen Dijkstra, Between academics and idiots. A cultural history of mathematics in the Dutch province of Friesland (16001700), Enschede (2012).

Dopper 2014: Jantien Dopper, A life of learning in Leiden. The mathematician Frans van Schooten (1615-1660), Utrecht (2014).

Engelsman 1978: S. B. Engelsman, Het Wiskundig Genootschap en eerste secretaris Strabbe, in: R.H. de Jong, T.W.M. Jongmans and P.H. Krijgsman (eds.), Tweehonderd jaar Onvermoeide Arbeid, Amsterdam: Wiskundig Genootschap (1978), 9-19.

Engelsman 2004: Steven Engelsman, Het monument van oprichting, in: Nieuw Archief voor Wiskunde (V) 5 (2004), 129-130.

Kool 1999: Marjolein Kool, "Die conste vanden getale”. Een studie over Nederlandstalige rekenboeken uit de vijftiende en zestiende eeuw, Hilversum: Verloren (1999).

Krüger 2014: Jenneke Krüger, Actoren en factoren achter het wiskundecurriculum sinds 1600, Utrecht (2014).

Montucla 1784-1804: Jean Etienne Montucla, Historie der wiskunde, Amsterdam: erven F. Houttuyn (1782-1804) [Four volumes, translation by A. B. Strabbe of French original].

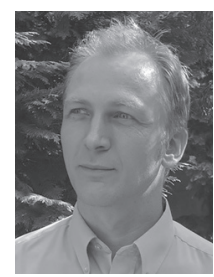

Danny Beckers (d.j.beckers@vu.nl) teaches history of mathematics and history of computer science at Vrije Universiteit Amsterdam. His research interests are in the history of 19th and 20th century mathematics and science education. 